\title{
Microspatial distribution of molluses and response of species to litter moisture, water levels and eutrophication in moist, alkaline ecosystems
}

\author{
Zofia Książkiewicz-Parulska $^{1,{ }^{*}}$ \& Jonathan D. Ablett ${ }^{2}$ \\ ${ }^{1}$ Department of General Zoology, Faculty of Biology, Adam Mickiewicz University, \\ Umultowska 89, 61-614 Poznań, Poland. \\ ${ }^{2}$ Natural History Museum, Department of Life Sciences, London, SW7 5BD, UK. \\ ${ }^{*}$ Corresponding author: zofia.ksiazkiewicz@gmail.com
}

\begin{abstract}
We investigated the influence of litter moisture, water levels and eutrophication on the microspatial distribution of terrestrial molluscs as well as their responses to the aforementioned factors. The studies were carried out in two moist, alkaline habitats in western Poland, differing in a range of environmental conditions. Redundancy Analysis showed that litter moisture was the leading factor affecting the microspatial distribution of the snails. To analyse the relationships between species abundance and litter moisture and water levels we determined a generalized linear model (GLM). The results of the analysis show that the abundance of the majority of the species decreased with increasing eutrophication. The abundance of the majority of species increased with increase in litter moisture at the Ilanka site, whereas conversely at the Pliszka site, the majority of the species showed a decreasing abundance with increasing litter moisture. The limiting factor at the Pliszka site was probably local inundations as well as litter and plant cover.
\end{abstract}

KEYWORDS. Gastropoda, microclimatic conditions, species' response curve, Vertigo angustior, Vertigo moulinsiana, Vertiginidae.

Książkiewicz-Parulska Z. \& Ablett J.D. 2017. Microspatial distribution of molluscs and response of species to litter moisture, water levels and eutrophication in moist, alkaline ecosystems. Belgian Journal of Zoology 147 (1): 37-53. https://doi.org/10.26496/bjz.2017.3

\section{Introduction}

The relationships between terrestrial gastropods and water availability and relative air humidity are well known. Molluscs have permeable skin and undergo high rates of dehydration (LUNCHTEL \& DEYRUPOLSEN 2001) and water is needed to produce the mucus that snails use for crawling. Dampness also determines the amount of time that molluscs spend feeding and breeding (BOYCOTT 1934). The loss of water from the skin of terrestrial snails varies with the humidity of the air, and once they are dehydrated beyond a certain point they are immobilized and then die (BOYCOTT 1934). Thus, distribution has been considered in relation to air humidity (i.e., MORENO-RUEDA et al. 2009; NUNES \& SANTOS 2012), water levels (TATTERSFIELD \& MCINNES 2003; KUCZYŃSKA \& MOORKENS 2010; KSIĄŻKIEWICZ et al. 2013) and moisture levels within the litter, which seems to be especially important for the smaller 
litter-dwelling snails (KUCZYŃSKA \& MOORKENS 2010; HETTENBERGEROVÁ et al. 2013; JANKOWIAK \& BERNARD 2013; KSIĄŻKIEWICZ et al. 2013).

One of the most important mechanisms for avoiding excess loss or gain of water is the selection of favorable microhabitats (LUCHTEL \& DEYRUP-OLSEN 2001), which are related to specific plant cover (e.g., KARLIN 1961; HORSÁK \& HÁJEK 2003; STOLL et al. 2012) and litter texture (SZYBIAK et al. 2009; KSIĄŻKIEWICZ et al. 2013). Some authors have shown that multiple land snail species tend to accumulate at the most favorable sites rather that one species replacing another at such sites (e.g., BOYCOTT 1934; WALDÉN 1981; HYLANDER et al. 2005; HORSÁK \& CERNOHORSKY 2008). Thus mollusc species and individuals are rarely if ever distributed at random within a site (CAMERON \& POKRYSZKO 2005) and are frequently found aggregated together (e.g., BOESVELD 2005; KSIĄŻKIEWICZ-PARULSKA \& PAWLAK 2016). Such a tendency may be explained by the 'nested habitat quality hypothesis', which implies that species in an assemblage increase in abundance along the same environmental gradient but differ in specialization or tolerance (HYLANDER et al. 2005). This hypothesis also implies that inter- and intraspecific competition is weak in such communities (HYLANDER et al. 2005).

Most of the previous studies have considered the occurrence of snails on a macroscale (e.g., KARLIN 1961; Willig et al. 1998; HORSÁK \& HÁJEK 2003; HORSÁK et al. 2007; SANTOS et al. 2012; SULIKOWSKADROZD \& HORSÁK 2007; MORENO-RUEDA 2014; KSIĄŻKIEWICZ \& GOŁDYN2015) and much less is known about the microspatial distribution of species within a site (e.g., NEKOLA \& SMITH 1999; JUŘIČKOVA et al. 2008; CERNOHORSKY et al. 2010; KUCZYŃSKA \& MOORKENS 2010; HETTENBERGEROVÁ et al. 2013; JANKOWIAK \& BERNARD 2013; KSIĄŻKIEWICZ et al. 2013; MYŠÁK et al. 2013; HORSÁK et al. 2014) or about the response of species to particular environmental factors (HORSÁK 2006; ČEJKA \& HAMERLÍK 2009). Additionally, only a few studies were supported by direct measurements of moisture within a site (i.e., HETTENBERGEROVÁ et al. 2013; KSIĄŻKIEWICZ et al. 2013). In this study we investigated the impact of litter moisture and water levels, as well as the effect of eutrophication, on the microspatial distribution of small and medium-sized terrestrial species of molluscs (the shell of the smallest species was $0.8 \mathrm{~mm}$ in height and $1.6 \mathrm{~mm}$ in width while the biggest was $6 \mathrm{~mm}$ in height and $9 \mathrm{~mm}$ in width). We also checked for the response of the studied species to the aforementioned factors. The study was carried out in two neighbouring moist, alkaline ecosystems in western Poland. The first site was highly affected by eutrophication with ground water levels never reaching the surface, while the second was locally flooded and with low levels of eutrophication. We hypothesized that (I) within the studied factors, litter moisture would be the most important for the distribution of the snail species in the studied sites and (II) that abundances of most of the studied species would increase along with increasing litter moisture.

\section{Material and methods}

\section{Study area}

The study was conducted in western Poland at two sites located in the valleys of small lowland rivers: Pliszka and Ilanka. Both rivers have similar parameters: their lengths do not exceed 60 kilometres and their catchment areas are approximately $440 \mathrm{~km}^{2}$. Both rivers are tributaries of the Odra river: the Ilanka flows into the Odra at $566.9 \mathrm{~km}$ along the river course and the Pliszka at $578.7 \mathrm{~km}$ (IOŚ 2002).

Most of the habitats associated with the Pliszka and Ilanka rivers are alkaline, with high moisture content and are locally flooded (STAŃKO \& WOŁEJKO 2001). The banks of the Ilanka and the Pliszka are dominated by sedge meadows that were previously used for pasture. They are surrounded by oak and pine forests.

Annual mean precipitation in this region is approximately $600 \mathrm{~mm}$ and annual mean temperature is about $8^{\circ} \mathrm{C}$ (PRAWDZIC \& KoŹMIŃSKI 1972). The studied sites were located about $80 \mathrm{~m}$ a.s.l. 


\section{Study sites}

The Pliszka site $\left(52^{\circ} 14^{\prime} 46.5^{\prime \prime} \mathrm{N}, 15^{\circ} 10^{\prime} 11.1^{\prime \prime} \mathrm{E}\right.$, ca. 0.20 ha in area) is treeless and locally flooded (approximately $35 \%$ of the site is a permanent marsh wetland). Ground water level varied from -20 $\mathrm{cm}$ to $+5 \mathrm{~cm}$ above the surface during the period of our study. Average soil moisture content in the microhabitats sampled during the two seasons was $74.9 \%(\sigma=15.7), \mathrm{pH} \approx 7.8$. Plant cover was usually lush and the most abundant plant species at the site were Carex acutiformis, Carex paniculata and Thelypteris palustris. Moss cover was well developed, especially in the central part of the site. This area, however, was devoid of, or poor in litter layer. The most dominant mosses were Plagniomnium elatum and Brachytecium rutabulum while Sphagnum squarosum and Climacium dendroides occurred locally.

The site in the Ilanka river valley $\left(52^{\circ} 20^{\prime} 09.7^{\prime \prime} \mathrm{N}, 15^{\circ} 03^{\prime} 07.3^{\prime \prime} \mathrm{E}\right.$; ca. 0.15 ha in area) was densely covered by Carex acutiformis and Urtica dioica and had undergone local eutrophication. Moss cover at this site was poorly developed and only small patches of Brachytecium rutabulum and Plagiomnium elatum were recorded. The litter layer, however, was well developed and thicker than at the Pliszka site. The site had not been flooded during the previous ten years, even after heavy rains. Ground water level varied from $-20 \mathrm{~cm}$ to $-5 \mathrm{~cm}$ during the period of our study and the average soil moisture content was $78.5 \%(\sigma=17.8), \mathrm{pH} \approx 7.6$. The habitat is fairly open and the northern section is partly shaded by alders.

Both sites were extensively utilised in the past. The area of the Ilanka and Pliszka valleys was economically exploited till the 1950s when such activities began to gradually disappear. Nowadays, the area is not used by humans except for the purposes of forestry and hunting (WOŁEJKO \& STAŃKO 1998).

\section{Data collection}

Both sites were sampled biweekly during the spring and summer months in 2008 (nine sampling events at Pliszka, 10 at Ilanka) and 2009 (seven - Pliszka; seven - Ilanka). Five sampling events were later excluded from the statistical analyses - see the 'Statistical analyses' section. At each site four parallel transects were laid out; along each transect four samples of litter were collected at $10 \mathrm{~m}$ intervals using a $0.25 \times 0.25 \mathrm{~m}$ Økland frame $\left(0.0625 \mathrm{~m}^{2}\right.$ in area) (ØKLAND 1929) (Figure 1). These transects were permanent and sampling was carried out repeatedly along each of them. Samples were never collected from the exact same place/square; previously sampled squares were marked with coloured sticks to prevent resampling, and successive samples were collected from adjacent places, within a distance of approximately $2 \mathrm{~cm}$.

Methodology, described by SHARLAND (2001), was applied for material collection. We harvested all loose litter and dead vegetation cut from the soil and root-mat to a depth of $5 \mathrm{~cm}$, and collected all vegetation to ground level. During each sampling event data on litter moisture (using a Nortene 5070141 hygrometer), ground water levels and eutrophication were collected for each quadrat. Ground water level fluctuations during each season were measured using a piezometer and characterised on a 5-degree scale using the following ranges: (1): $-15 \mathrm{~cm}$ to $-20 \mathrm{~cm}$; (2): $-10 \mathrm{~cm}$ to $-15 \mathrm{~cm},(3):-5 \mathrm{~cm}$ to $-10 \mathrm{~cm}$; (4): 0 to $-5 \mathrm{~cm}$; (5): water above the ground surface. Eutrophication was assessed using ecological indicator values of vascular plants of Poland developed by ZARZYCKI et al. (2002). The following scale was used: (1) soil very poor (extremely oligotrophic), (2) soil poor (oligotrophic), (3) soil moderately poor (mesotrophic), (4) soil rich (eutrophic), (5) soil very rich (extremely fertile).

In the laboratory, litter and soil samples were dried and divided into two fractions using a $0.5 \mathrm{~mm}$ sieve. Particles passing through the sieve were checked manually for the presence of snails under a stereo microscope. The retained fraction and cut plants were carefully examined for snails using a magnifying glass. Only living individuals were considered for the analyses.

Snails were identified to species level using descriptions provided by POKRYSZKO (1990), WIKTOR (2004) and KUŹNIK-KOWALSKA (2011). Nomenclature was adopted from WIKTOR (2004). Large species such as Arianta arbustorum, Cepaea nemoralis and Fruticicola fruticum were excluded from analyses 
because of the inadequacies of the sampling method (these species are too large for the sampling with a frame of $0.25 \times 0.25 \mathrm{~m}$ ). Juvenile individuals of Carychium minimum and $C$. tridentatum were divided proportionally between these two species depending on the number of adult individuals, since determination of juveniles to the species level is problematic (due to the lack of columellar lamella).

\section{Statistical analyses}

The differences in environmental conditions between the studied sites were tested with one-way ANOVA, randomized version. For these calculations we used RundomPro 3.14 software.

To determine which type of canonical analysis was the most appropriate to test for the influence of microhabitat parameters on the snail species distribution, we first ran the DCA(Detrended Correspondence Analysis) to estimate gradient lengths. The DCA gradient lengths for the first four axes are short $(<3)$ for data from Ilanka and Pliszka sites calculated separately, and together for both sites, therefore a Redundancy Analysis (RDA) was used in the further analyses (TER BRAAK \& ŠMILAUER 2003).

We used the following environmental factors as explanatory variables: litter moisture, water levels and eutrophication. For each of the RDA models for the Ilanka and Pliszka sites, data on environmental factors and snail densities were introduced and grouped using co-variables separating the blocks of data from particular seasons and days (see supplementary data files). In the case of the model applied for data from Ilanka and Pliszka sites together, data on environmental factors and snail densities were introduced and grouped using co-variables separating the blocks of data from particular seasons, days and sites. Species data were log-transformed prior to the analyses. Forward selection of environmental variables was applied while creating the models. To determine the statistical significance of explanatory variables as well as the significance of the models created, a Monte Carlo permutation test set for

\section{SITE}

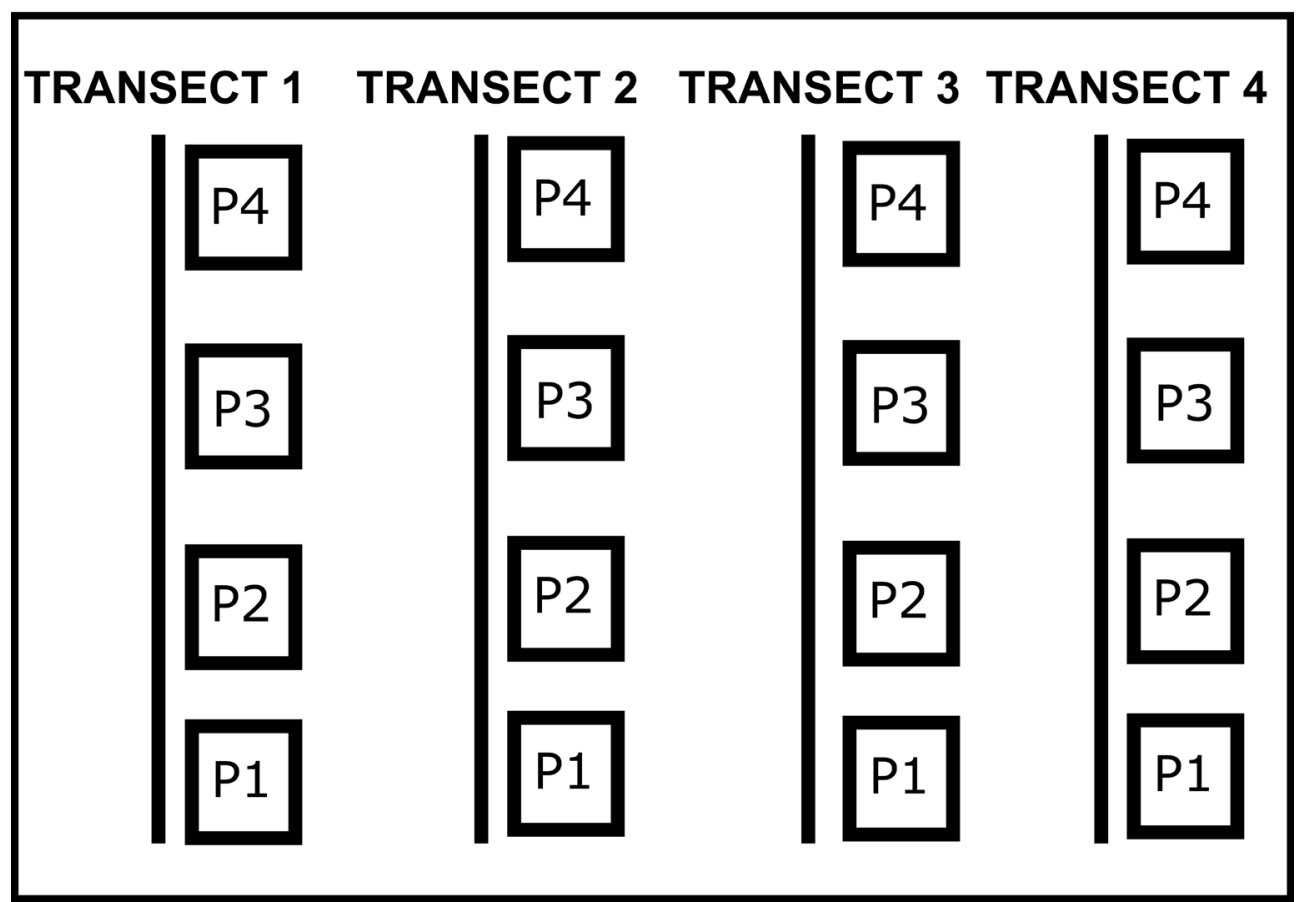

Figure 1 - Study design within the study sites: at each site 4 parallel transects were permanently designated and along each of them four samples were collected (P1-P4) with the $0.25 \times 0.25 \mathrm{~m}$ Økland frame at each sampling event. Since sample collection disturbed the sampled square, successive samples were collected from adjacent places within approximately $2 \mathrm{~cm}$. 
TABLE 1

Total number of individuals of studied species from samples collected at the Ilanka and Pliszka sites in 2008 and 2009. The table includes individuals collected from samples that were used in the statistical analyses and shows the abbreviated species names used in the RDA diagrams.

\begin{tabular}{lccc}
\hline \multicolumn{1}{c}{ Species } & \multicolumn{2}{c}{ Number of individuals } & Abbreviation \\
& Ilanka & Pliszka & \\
\hline Vertigo angustior Jeffreys, 1830 & 5555 & 745 & Vang \\
Vertigo moulinsiana (Dupuy, 1849) & 104 & 171 & $\mathrm{Vm}$ \\
Vertigo substriata (Jeffreys, 1833) & 0 & 458 & $\mathrm{Vs}$ \\
Vertigo antivertigo (Draparnaud, 1801) & 0 & 35 & $\mathrm{Vant}$ \\
Vertigo pygmaea (Draparanud, 1801) & 129 & 0 & $\mathrm{Vpyg}$ \\
Columella edentula (Draparnaud, 1805) & 393 & 10 & $\mathrm{Ce}$ \\
Vallonia costata (O.F. Müller, 1774) & 1887 & 0 & $\mathrm{Vco}$ \\
Vallonia pulchella (O.F. Müller, 1774) & 101 & 42 & $\mathrm{Vpu}$ \\
Nesovitrea hammonis (Ström, 1765) & 705 & 719 & $\mathrm{Nh}$ \\
Vitrea crystallina (O.F. Müller, 1774) & 1348 & 416 & $\mathrm{Vc}$ \\
Zonitoides nitidus (O.F. Müller, 1774) & 107 & 32 & $\mathrm{Zn}$ \\
Punctum pygmaeum (Draparnaud, 1801) & 431 & 354 & $\mathrm{Pp}$ \\
Vitrina pellucida (O.F. Müller, 1774) & 34 & 2 & $\mathrm{Vpe}$ \\
Carychium minimum O.F. Müller, 1774 & 2250 & 1386 & $\mathrm{Cm}$ \\
Carychium tridentatum (Risso, 1826) & 3688 & 674 & $\mathrm{Ct}$ \\
Perforatella bidentata Gmelin, 1791 & 585 & 254 & $\mathrm{~Pb}$ \\
Cochlicpa lubrica (O.F. Müller, 1774) & 474 & 190 & $\mathrm{Cl}$ \\
Euconulus alderi (Montagu, 1803) & 123 & 64 & $\mathrm{Ea}$ \\
\hline
\end{tabular}

5,000 permutations was applied (JONGMAN et al. 1995; TER BRAAK 1996). To reduce the Type I error the permutations were performed on the reduced model (LEPŠ \& ŠMILAUER 2003). To minimise the influence of data autocorrelation, the permutations were restricted for split-plot design, with blocks of data from particular seasons and sites regarded as independent whole-plots constituting four time series. The data from each sampling event were regarded as split-plots consisting of sampling plots arranged in a $4 \times 4$ grid (four parallel transects $\times$ four samples), nested within the whole-plots (LEPŠ \& ŠMILAUER 2003).

In some cases, when individual records were missing, they were replaced by the means from a corresponding sampling event (JONGMAN et al. 1995). In the case of five sampling events there was too much missing data and whole blocks representing such events were excluded from the analyses. In this way, the final analyses were conducted on the data for 13 sampling events (16 samples each) for the Pliszka site (seven in 2008 and six in 2009) and 15 for the Ilanka site (eight in 2008 and seven in 2009). To check for the response of species abundance to litter moisture, water levels and eutrophication, we ran a generalized linear model (GLM) using quadratic degree and the Poisson distribution with stepwise model selection using AIC statistics.

All the canonical analyses were performed using CANOCO for Windows 4.5 software package (TER BRAAK \& ŠMILAUER 2003). The graphs show species with fit to the ordination space higher than 5\%. 


\section{Results}

In total 23,466 live individuals of 18 studied species were recorded (16 species and 17,914 individuals from the Ilanka site; 16 species and 5,552 individuals from the Pliszka site) from 432 collected samples (233 from the Ilanka site and 199 from the Pliszka site) (Table 1). The one-way ANOVA shows that the study sites did not differ significantly with respect to litter moisture $(\mathrm{p}=0.562 ; \mathrm{F}=0.337)$, however at the Pliszka site water levels were significantly higher than at the Ilanka site $(\mathrm{p}<0.001 ; \mathrm{F}=60.057)$ while the Ilanka site showed significantly more eutrophication than the Pliszka site $(\mathrm{p}<0.001 ; \mathrm{F}=13.410)$.

\section{Microspatial distribution of snail species within the studied sites}

RDA analyses for the sites Ilanka $(\mathrm{p}<0.001 ; \mathrm{F}=14.092)$ and Pliszka $(\mathrm{p}<0.001 ; \mathrm{F}=6.306)$ as well as for both sites together $(\mathrm{p}<0.001 ; \mathrm{F}=13.467)$ revealed that moisture was the leading factor affecting microspatial distribution of the studied snail species (see Tables 2-4). Water levels were statistically significant within the Pliszka site and for both sites together (Tables 3-4) while eutrophication was statistically insignificant for all three models (Tables 2-4).

Within the Ilanka site most of the species preferred moist plots with the exception of Vitrea pellucida and Vertigo pygmaea (Figure 2), which preferred plots where moisture was the lowest. Within the Pliszka site Vertigo angustior preferred plots where water levels and moisture were relatively high while Carychium minimum and Vertigo moulinsiana preferred moist plots. Carychium tridentatum preferred plots where water levels were the lowest while Nesovitrea hammonis, Vertigo substriata preferred plots where

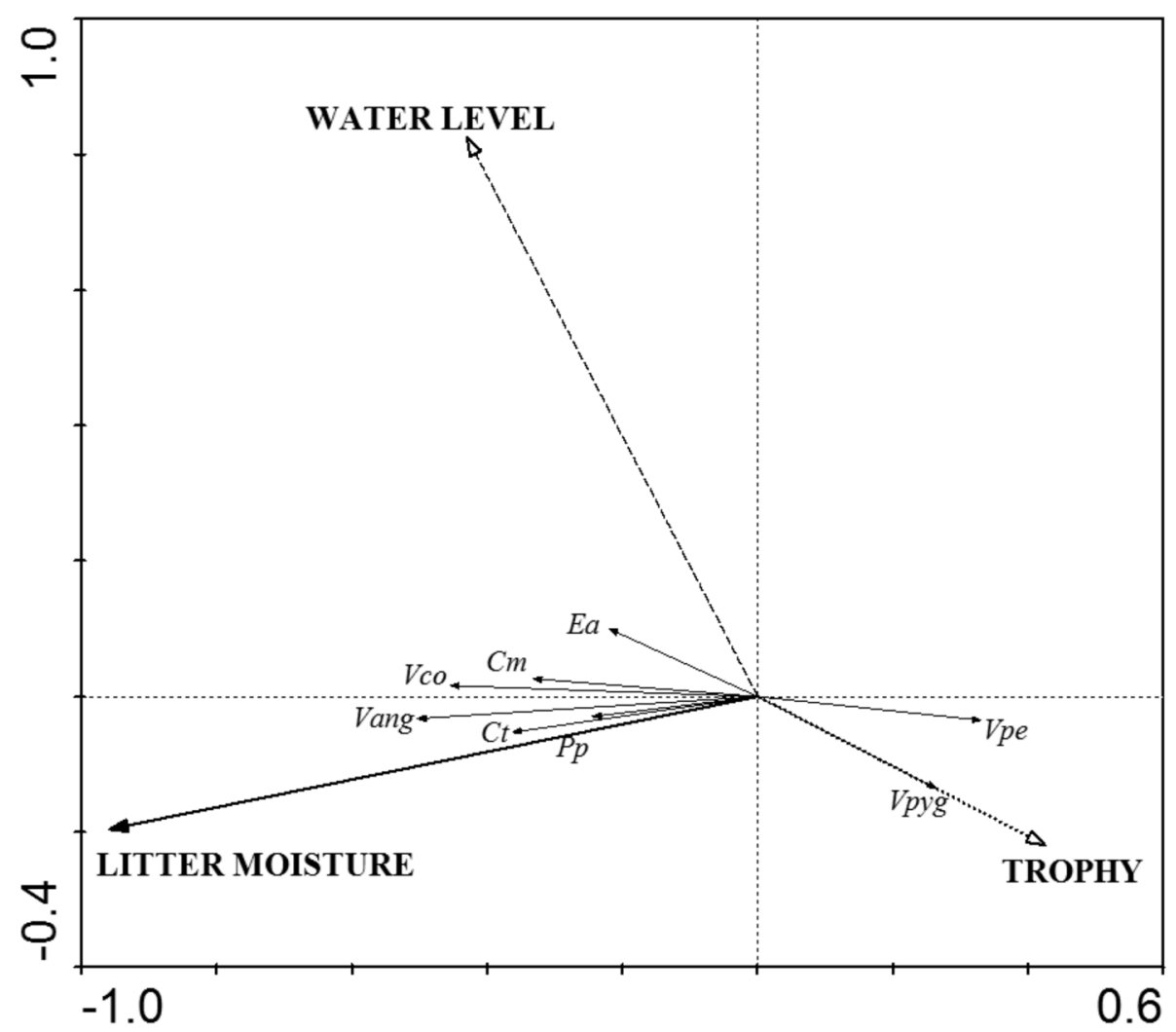

Figure 2 - Redundancy Analysis diagram showing the relationship between the factors studied and the densities of snail species at the Ilanka site. Abbreviations of the species' names are listed in Table 1. Statistically significant factors are marked by solid arrow lines and by a solid arrow, statistically insignificant variables by empty arrows. Model significance (Monte Carlo permutation test): $\mathrm{p}<0.001$; $\mathrm{F}=10.932$. 
TABLE 2

Results of forward selection on environmental variables in the Redundancy Analysis testing for the environmental factors influencing the distribution of gastropods species at the Ilanka site.

\begin{tabular}{lccc}
\hline Variable & variance explained $[\%]$ & $\mathrm{p}$ & $\mathrm{F}$ \\
\hline litter moisture & 12 & $<0.001$ & 37.43 \\
water level & 0 & 0.092 & 2.83 \\
trophy & 10 & 0.075 & 1.61 \\
\hline
\end{tabular}

both moisture and water levels were the lowest. Vitrea crystallina preferred plots where litter moisture was the lowest within the site (Figure 3). The analyses for both sites revealed that $V$. moulinsiana and C. minimum preferred moist plots while Vallonia costata and $V$. angustior preferred moist plots where water levels were high within the sites (Figure 4). On the other hand, V. pellucida preferred plots where moisture and water levels were the lowest within the sites.

\section{Responses of mollusc species to litter moisture, water levels and eutrophication}

A GLM was determined for 16 species from the Ilanka and Pliszka sites as well as for 18 species that were recorded at both sites. In the case of litter moisture GLM was statistically significant for 14 species

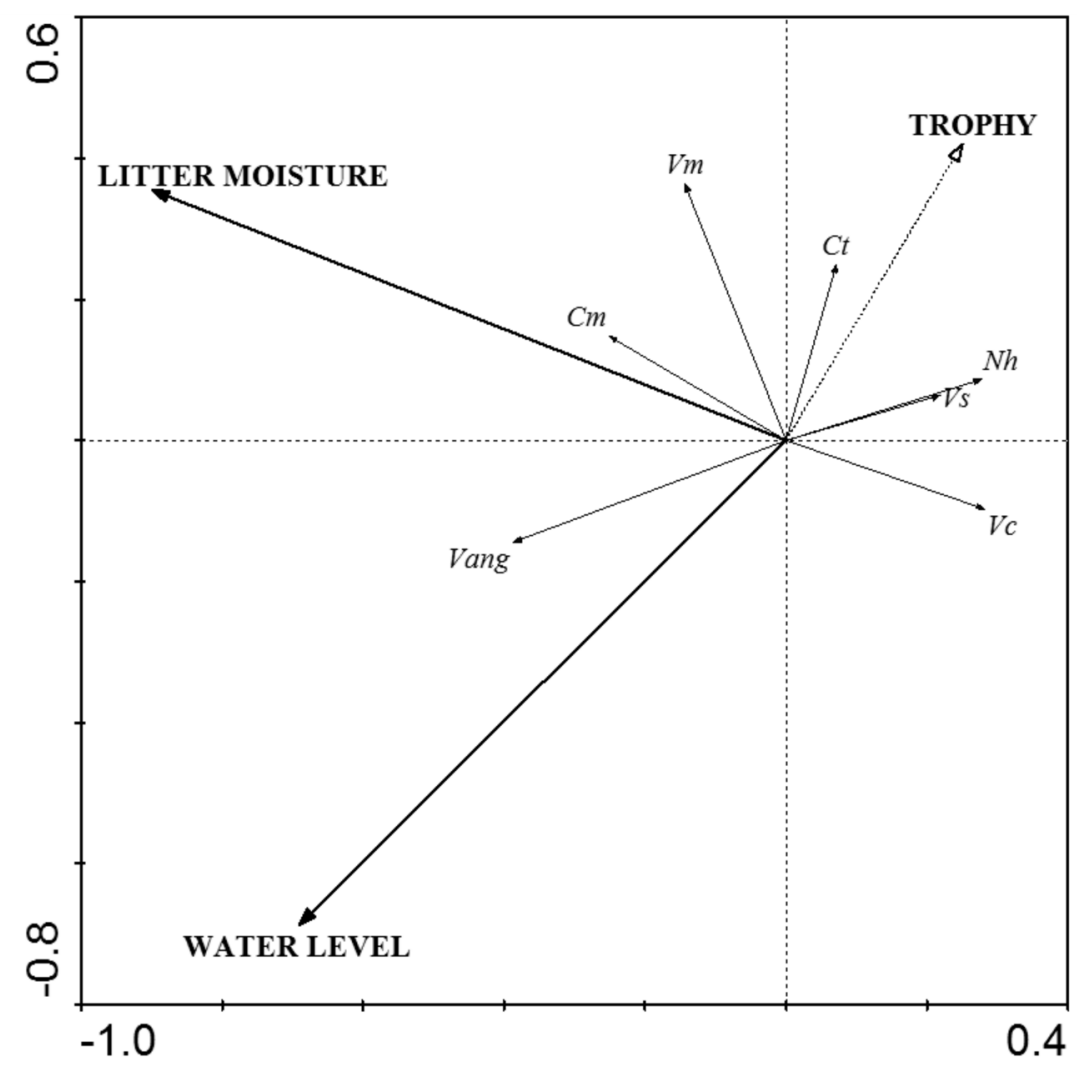

Figure 3 - Redundancy Analysis diagram showing the relationship between the factors studied and the densities of snail species at the Pliszka site. Abbreviations of the species' names are listed in Table 1. Factors statistically significant are marked by a solid arrow, statistically insignificant variables by empty arrows. Model significance (Monte Carlo permutation test): $\mathrm{p}=0.003 ; \mathrm{F}=4.199$. 


\section{TABLE 3}

Results of forward selection on environmental variables in Redundancy Analysis testing for the environmental factors influencing the distribution of gastropods species at the Pliszka site.

\begin{tabular}{lccc}
\hline Variable & variance explained $[\%]$ & $\mathrm{p}$ & $\mathrm{F}$ \\
\hline litter moisture & 5 & $<0.001$ & 10.92 \\
water level & 3 & $<0.001$ & 6.90 \\
trophy & 0 & 0.518 & 0.80 \\
\hline
\end{tabular}

at the Ilanka site, for nine species at the Pliszka site and for 16 species at both sites. In the case of water levels, GLM was statistically significant for 11 species at the Ilanka site, for 10 species at Pliszka and for 12 species at both sites. In the case of the eutrophication, GLM was statistically significant for eight species at the Ilanka site, for 2 species at the Pliszka site and for 11 species at both sites (Table 5).

In total, seven types of species' response curves (SRC) were distinguished (Figure 5): four of them describe the relationship between the species abundance and litter moisture (SRC: I, II, VI, VII, see Table 4), six describe the relationship between the species abundances and water levels (SRC: I, III, IV,

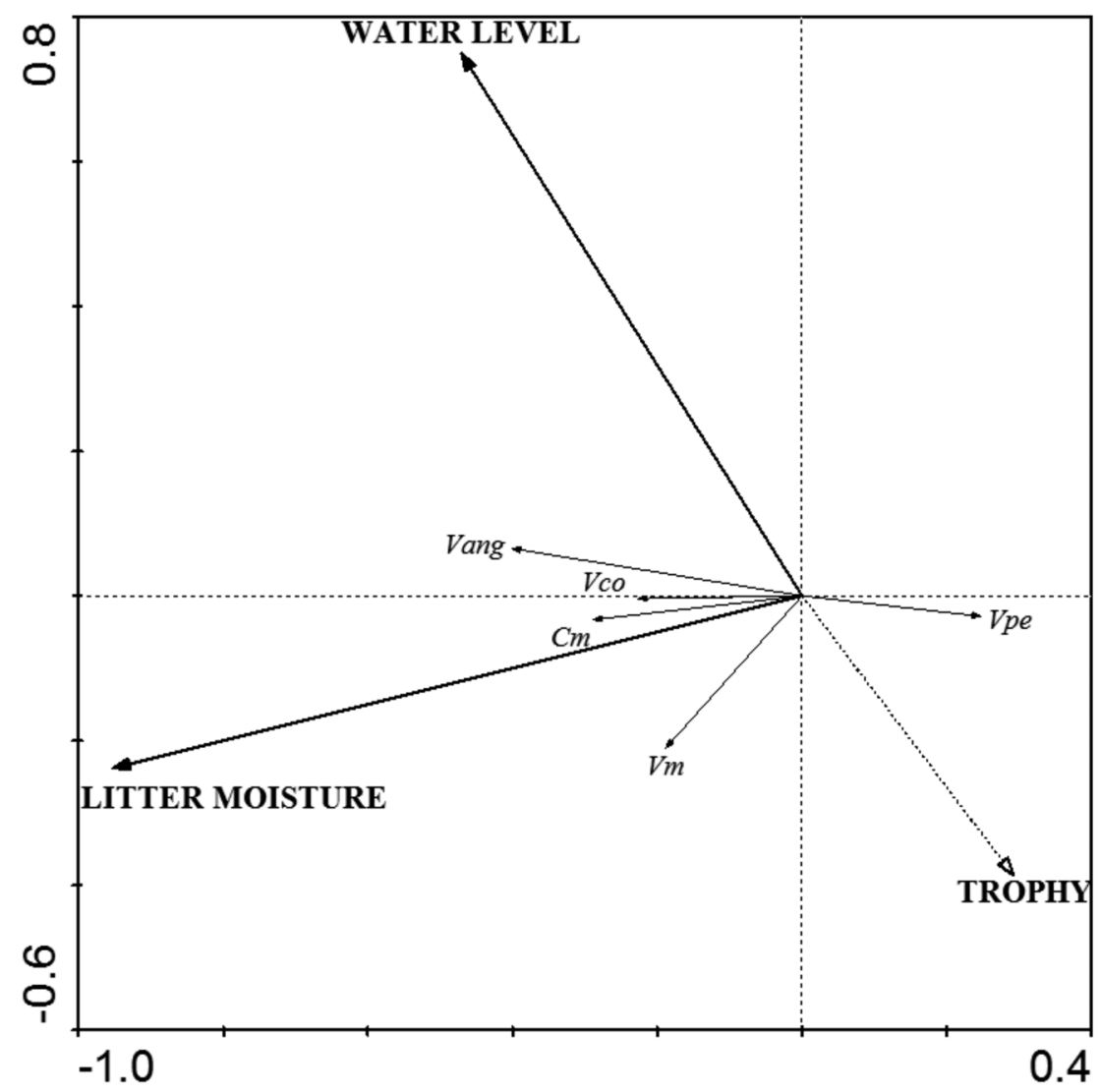

Figure 4 - Redundancy Analysis diagram showing the relationship between the factors studied and the densities of snail species at both sites combined. Abbreviations of the species' names are listed in Table 1. Factors statistically significant are marked by a solid arrow, statistically insignificant variables by empty arrows. Model significance (Monte Carlo permutation test): $\mathrm{p}=0.002 ; \mathrm{F}=35.982$. 
TABLE 4

Results of forward selection on environmental variables in Redundancy Analysis testing for the environmental factors influencing the distribution of gastropods species at the two studied sites combined.

\begin{tabular}{lccc}
\hline Variable & variance explained $[\%]$ & $\mathrm{p}$ & $\mathrm{F}$ \\
\hline litter moisture & 5 & $<0.001$ & 33.89 \\
water level & 1 & 0.011 & 4.89 \\
trophy & 0 & 0.210 & 1.30 \\
\hline
\end{tabular}

V, VI, VII) and four describe the relationship between the species abundance and eutrophication (SRC: I, III, IV, VII).

SRC I (litter moisture, water levels and eutrophication) - increasing monotonic response curve. Abundance of a species increased proportionally with increasing litter moisture, water levels or eutrophication. Such a response was seen at the Ilanka site; seven species showed such a response to litter moisture (e.g., C. minimum, V. costata), five species to water levels (e.g., V. angustior, V. moulinsiana, C. minimum) and one species for eutrophication ( $V$. crystallina). At the Pliszka site it was seen in two species in response to litter moisture (C. minimum, Euconulus alderi) and in one species for eutrophication (Perforatella bidentata). Such a response was also seen at both localities in the case of eight species for litter moisture (e.g., V. costata, Vallonia pulchella, C. minimum) and in three species for eutrophication (V. pygmaea, V. crystallina, V. pellucida).

SRC II (litter moisture) - increasing monotonic response curve. Abundances of the species remained low until the litter moisture reached 80-90\%; in such conditions abundances of the species increased sharply. This is the response shown by three species at the Ilanka site e.g., $V$. angustior and $V$. moulinsiana) and two species at the Pliszka site (i.e., V. moulinsiana and Vertigo antivertigo).

SRC III (water levels, eutrophication) - a skewed unimodal response curve was noted once for $V$. angustior in the Pliszka site for water levels (the species reached the highest abundances in water levels that varied from 0 to $-5 \mathrm{~cm}$ ). This response was shown by three species to eutrophication at both sites together (Columella edentula, V. costata, P. bidentata).

SRC IV (water levels, eutrophication) - a symmetrical unimodal response curve. Abundance of the species was the highest when water levels varied from $-15 \mathrm{~cm}$ to $-5 \mathrm{~cm}$ (Ilanka $-V$. costata, Punctum pygmaeum; Pliszka - V. substriata, V. crystallina, C. tridentatum, E. alderi). Abundance of the species was the highest when the eutrophication was close to 4 (both sites $-V$. angustior, $C$. tridentatum, E. alderi).
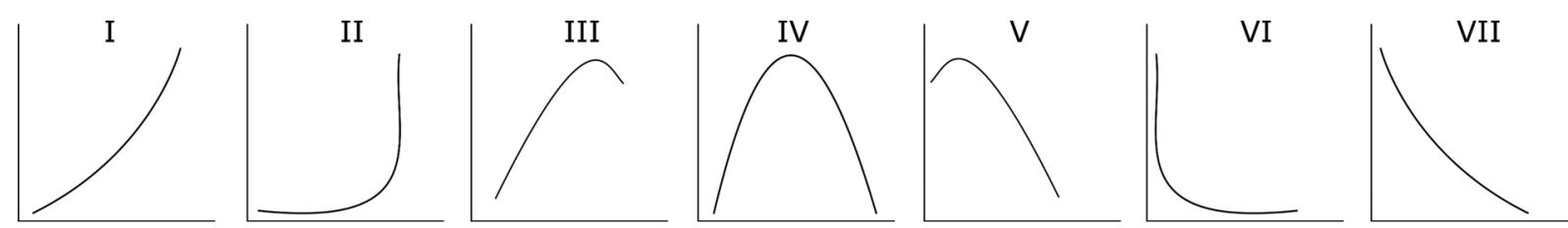

Figure 5 - Seven types of species response curves (SCR) distinguished in relation to the litter moisture, water levels and trophy level at the studied sites. 
TABLE 5

List of species processed by species response curve modelling at the Ilanka and Pliszka sites. Types of species response curves (SRC) are given in Figure 5.

\begin{tabular}{|c|c|c|c|c|c|c|c|c|c|}
\hline \multirow{3}{*}{ SPECIES } & \multicolumn{3}{|c|}{ ILANKA } & \multicolumn{3}{|c|}{ PLISZKA } & \multicolumn{3}{|c|}{ BOTH LOCALITIES } \\
\hline & \multicolumn{3}{|c|}{$\begin{array}{c}\text { LITTER MOISTURE } \\
\text { average } 78.5 \%(\sigma=17.8)\end{array}$} & \multicolumn{3}{|c|}{$\begin{array}{l}\text { LITTER MOISTURE } \\
\text { average } 74.9 \%(\sigma=15.7)\end{array}$} & \multicolumn{3}{|c|}{$\begin{array}{c}\text { LITTER MOISTURE } \\
\text { average } 77.6 \%(\sigma=16.7)\end{array}$} \\
\hline & SRC & $\mathrm{p}$ & $\mathrm{F}$ & SRC & $\mathrm{p}$ & $\mathrm{F}$ & SRC & $\mathrm{p}$ & $\mathrm{F}$ \\
\hline V. angustior & II & $<0.001$ & 50.6 & - & 0.164 & 1.82 & II & $<0.001$ & 55.44 \\
\hline V. moulinsiana & II & $<0.001$ & 15.39 & II & $<0.001$ & 28.09 & II & $<0.001$ & 39.06 \\
\hline V. substriata & - & - & - & VII & 0.003 & 9.23 & VII & 0.010 & 6.76 \\
\hline$V$ antivertigo & - & - & - & II & 0.019 & 5.51 & II & 0.041 & 4.21 \\
\hline V. pygmaea & VII & 0.02 & 4.83 & - & - & - & VII & 0.028 & 4.86 \\
\hline C. edentula & VII & 0.018 & 5.63 & - & 0.130 & 2.06 & VII & 0.032 & 4.65 \\
\hline V. costata & I & $<0.001$ & 23.92 & - & - & - & I & $<0.001$ & 39.14 \\
\hline V. pulchella & II & 0.003 & 8.60 & VII & 0.010 & 0.004 & I & 0.012 & 6.39 \\
\hline N. hammonis & - & 0.06 & 3.10 & VII & 0.014 & 6.09 & - & 0.154 & 0.167 \\
\hline V. crystallina & VII & $<0.001$ & 12.43 & VII & $<0.001$ & 11.97 & VII & $<0.001$ & 17.59 \\
\hline Z. nitidus & I & 0.006 & 7.58 & - & 0.23 & 0.201 & I & 0.032 & 4.65 \\
\hline P. pygmaeum & I & $<0.001$ & 15.01 & VII & 0.019 & 0.02 & $\mathrm{I}$ & 0.034 & 4.54 \\
\hline V. pellucida & VI & $<0.001$ & 18.49 & - & 0.06 & 2.96 & VI & $<0.001$ & 24.61 \\
\hline C. minimum & I & $<0.001$ & 28.79 & I & $<0.001$ & 15.01 & I & $<0.001$ & 45.07 \\
\hline C. tridentatum & I & $<0.001$ & 17.47 & - & 0.110 & 0.117 & I & $<0.001$ & 25.75 \\
\hline P. bidentata & - & 0.104 & 0.099 & - & 0.258 & 1.36 & - & 0.276 & 1.29 \\
\hline C. lubrica & I & $<0.001$ & 5.20 & - & 0.435 & 0.572 & I & 0.012 & 6.38 \\
\hline \multirow[t]{3}{*}{ E. alderi } & $\mathrm{I}$ & $<0.001$ & 12.38 & I & 0.017 & 0.018 & $\mathrm{I}$ & 0.002 & 9.63 \\
\hline & \multicolumn{3}{|c|}{$\begin{array}{c}\text { WATER LEVEL } \\
\text { varied from - } 20 \mathrm{~cm} \text { to }-5 \mathrm{~cm}\end{array}$} & \multicolumn{3}{|c|}{$\begin{array}{c}\text { WATER LEVEL } \\
\text { varied from }-20 \mathrm{~cm} \text { to }+5\end{array}$} & \multicolumn{3}{|c|}{$\begin{array}{c}\text { WATER LEVEL } \\
\text { varied from }-20 \mathrm{~cm} \text { to }+5\end{array}$} \\
\hline & SRC & $\mathrm{p}$ & $\mathrm{F}$ & SRC & $\mathrm{p}$ & $\mathrm{F}$ & SRC & $\mathrm{p}$ & $\mathrm{F}$ \\
\hline V. angustior & I & 0.007 & 7.53 & III & $<0.001$ & 14.48 & IV & 0.002 & 6.38 \\
\hline V. moulinsiana & I & $<0.001$ & 12.37 & - & 0.373 & 0.47 & - & 0.441 & 0.82 \\
\hline V. substriata & - & - & - & IV & 0.001 & 4.67 & - & 0.060 & 2.95 \\
\hline$V$ antivertigo & - & - & - & - & 0.140 & 0.15 & - & 0.209 & 0.234 \\
\hline V. pygmaea & VII & $<0.001$ & 11.25 & - & - & - & VI & $<0.001$ & 34.61 \\
\hline C. edentula & VII & $<0.001$ & 14.87 & - & 0.1 & 2.35 & $\mathrm{~V}$ & $<0.001$ & 24.42 \\
\hline V. costata & IV & $<0.001$ & 9.02 & - & - & - & IV & $<0.001$ & 16.11 \\
\hline V. pulchella & - & 0.495 & 0.71 & - & 0.280 & 0.34 & - & 0.490 & 0.68 \\
\hline N. hammonis & - & 0.066 & 2.75 & VII & 0.002 & 10.39 & - & 0.323 & 1.13 \\
\hline V. crystallina & VII & $<0.001$ & 11.25 & IV & 0.001 & 4.67 & VII & $<0.001$ & 35.45 \\
\hline Z. nitidus & - & 0.081 & 2.55 & VII & 0.02 & 5.38 & - & 0.110 & 2.21 \\
\hline P. pygmaeum & IV & $<0.001$ & 6.16 & VII & 0.003 & 6.11 & IV & $<0.001$ & 8.69 \\
\hline V. pellucida & VI & $<0.001$ & 17.67 & VI & $<0.001$ & 11.08 & VI & $<0.001$ & 30.06 \\
\hline C. minimum & I & 0.006 & 7.59 & - & 0.444 & 0.59 & IV & 0.008 & 4.87 \\
\hline C. tridentatum & I & $<0.001$ & 17.92 & IV & $<0.001$ & 10.12 & $\mathrm{~V}$ & $<0.001$ & 43.97 \\
\hline P. bidentata & - & 0.307 & 0.37 & VII & 0.04 & 4.60 & V & $<0.001$ & 8.67 \\
\hline C. lubrica & - & 0.41 & 0.332 & - & 0.435 & 0.572 & $\mathrm{~V}$ & 0.006 & 5.19 \\
\hline \multirow[t]{3}{*}{ E. alderi } & $\mathrm{I}$ & 0.031 & 4.72 & IV & 0.02 & 4.27 & IV & $<0.001$ & 7.12 \\
\hline & \multicolumn{3}{|c|}{$\begin{array}{l}\text { TROPHY VALUE } \\
\text { varied from } 4 \text { to } 5\end{array}$} & \multicolumn{3}{|c|}{$\begin{array}{l}\text { TROPHY VALUE } \\
\text { varied from } 3 \text { to } 5\end{array}$} & & $\begin{array}{l}\text { PHY VA } \\
\text { d from } 3\end{array}$ & \\
\hline & SRC & $\mathrm{p}$ & $\mathrm{F}$ & SRC & $\mathrm{p}$ & $\mathrm{F}$ & SRC & $\mathrm{p}$ & $\mathrm{F}$ \\
\hline V. angustior & VII & 0.009 & 6.88 & VII & 0.003 & 5.93 & IV & 0.024 & 3.75 \\
\hline V. moulinsiana & - & 0.080 & 2.99 & - & 0.122 & 2.13 & - & 0.078 & 2.56 \\
\hline V. substriata & - & - & - & - & 0.119 & 0.127 & VII & 0.004 & 5.52 \\
\hline$V$ antivertigo & - & - & - & - & 0.404 & 0.518 & - & 0.241 & 0.276 \\
\hline V. pygmaea & - & 0.071 & 3.26 & - & - & - & I & 0.002 & 9.84 \\
\hline C. edentula & - & 0.373 & 0.797 & - & 0.285 & 1.26 & III & $<0.001$ & 13.09 \\
\hline V. costata & VII & $<0.001$ & 12.34 & - & - & - & III & $<0.001$ & 15.24 \\
\hline V. pulchella & - & 0.110 & 2.58 & - & 0.129 & 0.139 & - & 0.330 & 1.11 \\
\hline N. hammonis & - & 0.312 & 1.03 & - & 0.543 & 0.418 & - & 0.462 & 0.773 \\
\hline V. crustallina & I & 0.036 & 4.45 & - & 0.151 & 0.164 & I & $<0.001$ & 16.66 \\
\hline Z. nitidus & - & 0.132 & 2.29 & - & 0.415 & 0.537 & - & 0.078 & 2.58 \\
\hline P. pygmaeum & VII & 0.008 & 7.16 & - & 0.223 & 1.51 & VII & 0.026 & 3.69 \\
\hline V. pellucida & - & 0.123 & 2.40 & - & 0.404 & 0.519 & I & 0.011 & 6.59 \\
\hline C. minimum & VII & 0.012 & 6.46 & - & 0.313 & 0.375 & - & 0.117 & 2.16 \\
\hline C. tridentatum & VII & 0.002 & 10.11 & - & 0.858 & 1.05 & IV & $<0.001$ & 11.70 \\
\hline P. bidentata & - & 0.231 & 1.45 & I & 0.003 & 9.19 & III & $<0.001$ & 9.43 \\
\hline C. lubrica & VII & 0.033 & 4.58 & - & 0.242 & 1.43 & - & 0.477 & 0.649 \\
\hline E. alderi & VII & 0.013 & 6.33 & - & 0.094 & 2.39 & IV & 0.001 & 7.00 \\
\hline
\end{tabular}


SRC V (water levels) - a skewed unimodal response curve. This response was seen in the species that reached the highest abundances in water levels that varied from $-5 \mathrm{~cm}$ to $-15 \mathrm{~cm}$ (both sites - C. edentula, C. tridentatum, P. bidentata, Cochlicopa lubrica).

SRC VI (litter moisture and water levels) - decreasing monotonic response curve. This response was shown by $V$. pellucida. Its abundance values were high in the lowest litter moisture conditions at the Ilanka site and at both sites combined. Abundances of this species were also high in conditions of high water levels at Ilanka and Pliszka sites and at both sites combined. The density of $V$. pellucida decreased sharply with increasing litter moisture/water levels. The same response was shown by V. pygmaea for water levels at both sites combined.

SRC VII (litter moisture, water levels and eutrophication) - decreasing monotonic response curve. Abundances of species decreased proportionally with increasing litter moisture, water levels or eutrophication. Such a response was shown by three species, namely $V$. pygmaea, C. edentula, $V$. crystallina for both environmental variables: litter moisture and water levels at the Ilanka site, as well as five species in response to the litter moisture (e.g., V. substriata, V. pulchella, N. hammonis, $V$. crystallina, P. pygmaeum) and four species (e.g., $N$. hammonis) in response to water levels at the Pliszka site. In the case of both sites such a response was shown by four species for the litter moisture (V. substriata, V. pygmaea, C. edentula, $V$. crystallina) and by one species ( $V$. crystallina) for water levels. The response was also shown in relation to eutrophication in the case of seven species at the Ilanka site (e.g. $V$. angustior, $V$. costata, $C$. minimum), one at the Pliszka site ( $V$. angustior) and by two species at both sites combined ( . substriata, P. pygmaeum).

\section{Discussion}

Redundancy Analyses run for Ilanka and Pliszka sites separately and both sites together showed that the litter moisture played a leading role in the microspatial distribution of snails. The GLM analysis for particular species at the Ilanka site revealed that abundances of the majority of species (namely 10 species) increased along with increasing moisture of the litter (SRC I, II). At the Pliszka site however, nine out of 16 species showed a statistically significant response to litter moisture and more than half of these species (five species) showed a decreasing monotonic response curve (SRC VII). On the other hand, the RDA analysis showed that water levels significantly affected the microspatial distribution of snails only within the locally inundated Pliszka site. According to GLM analysis the abundances of most of the species that showed a statistically significant response to this factor at the Pliszka site decreased along with increasing water levels (five out of nine species). Interestingly, at the non-inundated Ilanka site most of the species showed an increasing monotonic response curve to this factor (SRC I). Thus we suspect that local inundations at the Pliszka site most likely limited the distribution of snails, since most of them are litter dwellers that are unable to survive flooding.

The GLM analysis for data from both sites showed that the studied species usually reach the highest abundances at a particular degree of water level variation (SRC IV, V) and none of them showed the increasing monotonic response curve to this factor (SRC I). Conversely, most species showed an increasing monotonic response curve (SRC I) in response to the moisture of the litter. Thus when considering data from both sites, the studied species occurred at low abundances in inundated plots but most of them reached high abundance in highly moist plots. The GLM analyses for both sites should, however, be interpreted with caution, since the number of samples and abundances of the species were greater at the Ilanka site, and thus the data from this site could dominate the results of the analysis. For this reason we excluded the joined analyses from further considerations.

The data from the Ilanka site support the "nested habitat quality" description, since abundances of most of the studied species increased along with the increasing moisture of the litter. This hypothesis has already been proven for snails in the case of available calcium across a variety of habitats (WÄREBORN 
1969; MARTIN \& SOMMER 2004), for the fen communities and mineral richness (HORSÁK \& CERNOHORSKY 2008) and conductivity (HORSÁK et al. 2014). Some studies have also pointed out the relation between snail species richness and moisture (e.g., WÄREBORN 1969; MARTIN \& SOMMER 2004). HETTENBERGEROVÁ et al. 2013, however, stated that the snail species richness was positively correlated with the weight of dry biomass and cover of herb layer rather than moisture gradient. The relationship between snail species richness and plant cover has been already proven (e.g., KARLIN 1961; PORTS 1996; HORSÁK \& HÁJEK 2003). Such a relationship is not surprising since vegetation provides food (food of the smallest snails species consists of the remains of higher plants, fungi, lichens and algae; e.g., BОYCOTT 1934) and specific microhabitats related to the texture of the litter (KSIĄŻKIEWICZ et al. 2013; ONDINA et al. 2004; PEREA et al. 2007), which may in turn be related to retention capacity (KSIĄŻKIEWICZ 2012). The locally-flooded Pliszka site was also the more litter-poor, and such litterpoor plots were usually also temporarily flooded and covered with differing vegetation (a lack of sedges but well developed moss cover). Thus we cannot exclude the possibility that another factor also limiting the snail distribution was a lack of suitable plant cover as well as litter (thus weight of a dry biomass mentioned by HETTENBERGEROVÁ et al. 2013).

It should be noted that the species distributions and their abundances might have been also affected by some other factors that were not considered in this study, for example Ca availability (i.e., BURCH 1955; MARTIN \& SOMMER 2004) or pH (e.g., BURCH 1955; SULIKOWSKA-DROZD \& HORSÁK 2007; NEKOLA 2010). However, both sites are rich in calcium (WOŁEJKO et al. 2008; WOŁEJKO et al. 2012) and therefore this was probably not a major limiting factor affecting the molluscan communities (HORSÁK 2006).

HetTENBERGEROvÁ et al. (2013) also showed changes in the response of particular snail species to varying moisture. Some of the results presented by the aforementioned authors are similar to ours (for example the preferences of $V$. antivertigo and $V$. pellucida) but some of them differ. For example, Hettenbergeroví et al. (2013) reported that $V$. moulinsiana, $C$. minimum and $V$. substriata showed a preference for intermediate moisture conditions. According to our study $V$. moulinsiana and C. minimum are highly hygrophilous, while densities of $V$. substriata decreased with increasing litter moisture. Those authors also showed that $V$. angustior occurred evenly along the whole moisture gradient resulting in a non-significant response that is opposite to our results - according to our studies $V$. angustior is highly hygrophilous. HETTENBERGEROVÁ et al. (2013) also showed that $V$. pygmaea prefers moister plots while we found that it was more abundant in the driest plots at the Ilanka site. The results of our study are in accordance with findings of some other authors who have carried out research in similar habitat types in lowland Poland (JANKOWIAK \& BERNARD 2013 showed, e.g., similar preferences for moisture in $V$. pygmaea, $V$. angustior and $V$. moulinsiana; SZLAUER-ŁUKASZEWSKA et al. 2015 showed similar preferences for moisture in $V$. angustior, V. moulinsiana, C. minimum, C. tridentatum and V. costata). Thus, we suspect that the differences in the study of HETTENBERGEROVÁ et al. (2013) may have resulted from differences in climatic conditions and other types of habitat sampled. Perhaps, these authors also considered a wider gradient of moisture conditions than we did. The results presented in the previously mentioned papers as well as results of our study support the opinion that the microspatial distribution of a particular species depends on a particular combination of environmental factors (CAMERON 2003) as well as a range of tolerances to change within particular species.

In summary, we confirmed the hypothesis that the litter moisture is the most important factor affecting the distribution of the snails at the studied, alkaline sites. The hypothesis that the abundances of most of the studied species would increase along with increasing litter moisture was confirmed for the Ilanka site and this result supports the "nestedness habitat quality hypothesis" (HYLANDER et al. 2005). At the Pliszka site occurrence of the species was limited due to local inundation and probably a specific character of the flooded plots (characteristic of the litter and vegetation). This study also confirmed the observations of other authors that snail species have differing preferences to soil moisture conditions even at a fine, within-site scale (e.g., HETTENBERGEROVÁ et al. 2013; KSIĄŻKIEWICZ et al. 2013; JANKOWIAK 
\& BERNARD 2013) and that even visually homogenous areas may by environmentally heterogeneous at a microscale (MYŠÁK et al. 2013).

Since this study involved the presence of the threatened EU Vertigo species: V. angustior and $V$. moulinsiana (annex II of the Habitat Directive) as well as other hygrophilous Vertigo species whose ranges are decreasing due to climate and/or human activity (POKRYSZKO, 2003), this study also has implications for conservation. Since multiple snail species accumulate within the most favorable sites rather that replace each other (e.g., BOYCOTT 1934; WALDÉN 1981; HYLANDER et al. 2005; HORSÁK \& CERNOHORSKY 2008) and inter- and intra-specific competition is weak (BOYCOTT 1934; HYLANDER et al. 2005), we may expect that species richness and their abundance within the alkaline habitats will be highest at non-inundated but highly moist plots where the litter layer is well developed and particular plant species are present. The extremely fertile plots will be avoided by most of the species. On the other hand, the habitats that promote maintenance of populations of snail species are usually mosaics of microhabitats, which are dynamic systems that may promote different species when particular weather conditions occur (KSIĄŻKIEWICZ-PARULSKA \& ABLETT 2016). Looking at this issue from a wider perspective, and considering that these species frequently occur in habitats along the dynamic systems of river valleys (e.g., FALKNER 2003; KSIĄŻKIEWICZ 2009; KSIĄŻKIEWICZ et al. 2015), the existence of mosaics of different types of habitats should promote the maintenance of populations of many hygrophilous snails.

\section{Conclusions}

This study showed that litter moisture was the most important factor affecting the distribution of the snails at the studied, alkaline sites. The abundances of most of the studied species increased along with increasing litter moisture in the non-inundated and litter-rich Ilanka site, which supports the "nestedness habitat quality hypothesis" (HYLANDER et al. 2005). The occurrence of species at the Pliszka site was limited by local inundations, and probably the specific plant cover and litter characteristics also created limitations within the inundated plots. This study supports the opinion that multiple snail species accumulate within the most favorable sites rather that replace each other (e.g., BOYCOTT 1934; WALDÉN 1981; HYLANDER et al. 2005; HORSÁK \& CERNOHORSKY 2008). We also showed that the highest diversity of snail species and their abundance within the alkaline sites may be expected at noninundated but highly moist plots where the litter layer is well developed and particular plant species are present. The extremely fertile plots will be avoided by most of the species. This study also supports the suggestion that snail species have different preferences for soil moisture conditions even at a fine, withinsite scale (e.g., HETTENBERGEROvÁ et al. 2013; KSIĄŻKIEWICZ et al. 2013; JANKOWIAK \& BERNARD 2013). We also showed that the microspatial distribution of a particular species depends on a particular combination of environmental factors (CAMERON 2003).

\section{Acknowledgements}

The authors would like to thank Bartłomiej Gołdyn for valuable suggestions and helping with statistical section, Katarzyna Kiaszewicz and Robert Stańko for helping with the field research, Andreia Salvador for suggestions during preparation of the manuscript and James MacLaine and Rebecca Miles for their editorial comments. The authors are very grateful to Beata Pokryszko, Andrzej Lesicki, Henryk Okarma and Katarzyna Zając for valuable comments and suggestions on the $\mathrm{PhD}$ thesis of the first author, which was the base of the present paper, as well as Michal Horsák and Robert Cameron who gave valuable advice on an early draft of the paper. The authors are very grateful to Referees for their valuable comments that greatly improved this text. The first author of this paper was supported by the Malopołska scholarship fund for Ph.D. students. 


\section{References}

Boycott A.E. (1934). The habitats of land Mollusca in Britain. Journal of Animal Ecology 22: 1-38.

Boesveld A. (2005). Overwinteringsgedrag van de nauwe korfslak Vertigo angustior (Mollusca). Nederlandse Faunistische Mededelingen 22: 121-122.

BURCH J.B. (1955). Some ecological factors of the soil affecting the distribution and abundance of land snails in Western Virginia. Nautilus 69: 63-68.

TER BRAAK C.J.F. (1996). Unimodal methods to relate species to environment. Centre for Biometry Wageningen (DLO Agricultural Mathematics Group). Wageningen, the Netherlands.

TER BRAAK C.J.F. \& ŠMilAUER P. (2003). CANOCO Reference Manual and CanoDraw for Windows User's Guide: Software for Canonical Community Ordination (version 4.5). Centre for Biometry Wageningen, Ithaca, NY, USA.

CAMERON R.A.D. (2003). Life-cycles, molluscan and botanical assemblages of Vertigo angustior and Vertigo geyeri (Gastropoda: Pulmonata: Vertiginidae). Heldia 5: 95-110.

CAMERon R.A.D. \& PoKryszKo B.M. (2005). Estimating the species richness and composition of land mollusc communities: problems, consequences and practical advice. Journal of Conchology 38: 529-547.

ČEJKA T. \& HAMERLÍK L. (2009). Land snails as indicators of soil humidity in Danubian Woodland (SW Slovakia). Polish Journal of Ecology 57: 741-747.

CERnOHORSKY N., HorsÁK M. \& CAMERON R.A.D. (2010). Land snail species richness and abundance at small scales: the effect of distinguishing between live individuals and empty shells. Journal of Conchology 40: 233-241.

FALKNER G. (2003). The status of the four Annex II species of Vertigo in Bavaria (Gastropoda: Pulmonata: Vertiginidae). Heldia 5: 59-72.

Hettenbergerová E., Horsák M., Chandran R., Hájek M., ZelenÝ D. \& DvořÁkovÁ J. (2013). Patterns of Land Snail Assemblages along a Fine-Scale Moisture Gradient. Malacologia 56: 31-42.

HORSÁK M. (2006). Mollusc community patterns and species response curves along a mineral richness gradient: a case study in fens. Journal of Biogeography 33: 98-107. https://oi.org/10.1111/j.1365$\underline{2699.2005 .01359 . x}$

HorsÁK M. \& CERNOHORSKY N. (2008). Mollusc diversity patterns in Central European fens: hotspots and conservation priorities. Journal of Biogeography 35: 1215-1225. https://doi.org/10.1111/j.1365$\underline{\text { 2699.2007.01856.x }}$

HoRsÁK M., HÁJEK M., DíTĚ D. \& TiCHÝ L. (2007). Modern distribution patterns of snails and plants in the Western Carpathian spring fens: is it a result of historical development? Journal of Molluscan Studies 73: 53-60. https://doi.org/10.1093/mollus/eyl024

HoRsÁK M. \& HÁJEK M. (2003). Composition and species richness of mollusc communities in relation to vegetation and water chemistry in the Western Carpathian spring fens: the poor-rich gradient. Journal of Molluscan Studies 69: 349-357. https://doi.org/10.1093/mollus/69.4.349

HoRSÁK M., ZELENÝ D. \& HÁJEK M. (2014). Land snail richness and abundance along a sharp ecological gradient at two sampling scales: disentangling relationships. Journal of Molluscan Studies 80: 256-264. https://doi.org/10.1093/mollus/eyu027

Hylander K., Nilsson C., Jonsson B.G. \& GothneR T. (2005). Differences in habitat quality explain nestedness in a land snail metacommunity. Oikos 108: 351-361. 
IOŚ (2002). Wojewódzki Inspektorat Ochrony Środowiska w Zielonej Górze Delegatura w Gorzowie Wlkp. Komunikat o stanie czystości rzek badanych w 2001 roku, Gorzów Wielkopolski.

JANKOWIAK A. \& BERNARD R. (2013). Coexistence or spatial segregation of some Vertigo species (Gastropoda: Vertiginidae) in a Carex rich fen in Central Poland? Journal of Conchology 41: 399-406.

JONGMAN R.H.G., TER BRAAK C.J.F. \& VAN TONGEREN O.F.R. (1995). Data analysis in community and landscape ecology. Cambridge University Press, Cambridge.

JuŘiČKovÁ L., Horsák M., CAMERon R., Hylander K., MíkovcovÁ A., HlaVÁČ J.Č. \& RohoveC J. (2008). Land snail distribution patterns within a site: The role of different calcium sources. European Journal of Soil Biology 44: 172-179. https://doi.org/10.1016/j.ejsobi.2007.07.001

KARLIN E.J. (1961). Ecological relationships between vegetation and the distribution of land snails in Montana, Colorado, and New Mexico. The American Midland Naturalist 65: 60-66.

KSIĄŻKIEWICZ Z. (2009). New localities of Vertigo moulinsiana (Dupuy, 1849) (Gastropoda: Pulmonata: Vertiginidae) in northwestern Poland. Folia Malacologica 17: 219-222. https://doi.org/10.2478/v10125$\underline{009-0018-8}$

KSIĄŻKIEWICZ Z. (2012). Wymagania mikrosiedliskowe wybranych mięczaków szuwaru wielkoturzycowego ze szczególnym uwzględnieniem Vertigo angustior. Ph.D. Thesis. Instytut Ochrony Przyrody Polskiej Akademii Nauk, Kraków.

KSIĄŻKIEWICZ Z., BIEREŻNOJ-BAZILLE U., KRAJEWSKi Ł. \& GOŁDYN B. (2015). New records of Vertigo geyeri (Lindholm, 1925), V. moulinsiana (Dupuy, 1849) and V. angustior Jeffreys 1830 (Gastropoda: Pulmonata: Vertiginidae) in Poland. Folia Malacologica 23: 121-136. https://doi.org/10.12657/ folmal.023.006

KSIĄŻKIEWICZ Z., KIASZEWICZ K. \& GOŁDYN B. (2013). Microhabitat requirements of five rare vertiginid species (Gastropoda, Pulmonata: Vertiginidae) in wetlands of Western Poland. Malacologia 56: $95-107$. https://doi.org/10.4002/040.056.0207

KSIĄŻKIEWICZ Z. \& GOŁDYN B. (2015). Needle in a haystack: predicting the occurrence of wetland invertebrates on the basis of simple geographical data. A case study on two threatened micro-mollusc species (Gastropoda: Vertiginidae) from Poland. Wetlands 35: 667-675. https://doi.org/10.1007/s13157$\underline{015-0656-0}$

KSIĄŻKIEWICZ-PARULSKA Z. \& ABLETT J.D. (2016). Investigating the influence of habitat type and weather conditions on the population dynamics of land snails Vertigo angustior Jeffreys, 1830 and Vertigo moulinsiana (Dupuy, 1849). A case study from western Poland. Journal of Natural History 50: 1749-1758. https://doi.org/10.1080/00222933.2016.1156178

KSIĄŻKIEWICZ-PARULSKA Z. \& PAWLAK K. (2016). Rare species of micromolluscs in the city of Poznań (W. Poland) with some notes on wintering of Vertigo moulinsiana (Dupuy, 1849). Folia Malacologica 24: 97-101. https://doi.org/10.12657/folmal.024.007

KUCZYŃSKA A. \& MOORKENS E. (2010). Micro-hydrological and micro-meteorological controls on survival and population growth of the whorl snail Vertigo geyeri Lindholm, 1925 in groundwater fed wetlands. Biological Conservation 143: 1868-1875. https://doi.org/10.1016/j.biocon.2010.04.033

KUŹNIK-KowALSKA E. (2011). Age structure and growth rate of Zonitoides nitidus (O.F. Müller, 1774) (Gastropoda: Pulmonata: Gastrodontidae). Folia Malacologica 19: 51-53. https://doi.org/10.2478/ $\underline{\mathrm{v} 10125-011-0008-5}$

LEPŠ J. \& ŠMILAUER P. (2003). Multivariate analysis of ecological data using CANOCO. Cambridge University Press, Cambridge.

LuChtel D.L. \& DeYrup-Olsen I. (2001). Body Wall: Form and Function. In: BARKer G.M. (ed.) The Biology of Terrestrial Molluscs: 447-488. CABI Publishing, Trowbridge: 447-488. 
MARTIN K. \& SOMmeR M. (2004). Effects of soil properties and land management on the structure of grassland snail assemblages in SW Germany. Pedobiologia 48: 193-203.

Moreno-Rueda G., Ruiz-Ruiz A., Collantes-Martín E. \& Arrébola J.R. (2009). Relative importance of humidity and temperature on microhabitat use by land snails in arid versus humid environments. In: Fernandes-Bernal A. \& De la Rosa M.A. (eds) Arid Environments and Wind Erosion: 331-343. Nova Science Publishers, New York.

Moreno-RUEDA G. (2014). Distribution of arid-dwelling land snails according to dryness. Journal of Arid Environments 103: 80-84. https://doi.org/10.1016/j.jaridenv.2014.01.006

MyšÁk J., HorsÁk M., Svobodová E. \& Cernohorsky N. (2013). Small-scale distribution of terrestrial snails: patterns of species richness and abundance related to area. Journal of Molluscan Studies 27: 118-127. https://doi.org/10.1093/mollus/eyt002

NeKola J.C. (2010). Acidophilic terrestrial gastropod communities of North America. Journal of Molluscan Studies 76: 144-156. https://doi.org/10.1093/mollus/eyp053

NeKola J.C. \& SMith T.M. (1999). Terrestrial gastropod richness patterns in Wisconsin carbonate cliff communities. Malacologia 41: 253-269.

NunES G.K.M. \& SANTOS S.B. (2012). Environmental factors affecting the distribution of land snails in the Atlantic Rain Forest of Ilha Grande, Angra dor Reis, RJ. Brazilian Journal of Biology 72: 79-86.

ØKLAND F. (1929). Quantitative researches concerning the land-fauna, especially the molluscs. Rapport fra Det 18. Skandinaviske Naturforskermøde i København: 26-31.

Ondina P., HeRmida J., OUteIRo A. \& MATO S. (2004). Relationships between terrestrial gastropod distributon and soil properties in Galicia (NW Spain). Applied Soil Ecology 26: 1-9. https://doi. org/10.1016/j.apsoil.2003.10.008

Perea J., Garcia A., Gómez G., Acero R., PeÑa F. \& Gómez S. (2007). Effect of light and substratum structural complexity on microhabitat selection by the snail Helix aspersa Müller. Journal of Molluscan Studies 73: 39-43. https://doi.org/10.1093/mollus/eyl031

POKRYSZKO B.M. (1990). The Vertiginidae of Poland (Gastropoda: Pulmonata: Pupilloidea) a systematic monograph. Annales Zoologici 43: 133-257.

POKRYSZKO B.M. (2003). Vertigo in Continental Europe- autecology, threats and conservation status (Gastropoda, Pulmonata: Vertiginidae). Heldia 5: 13-25.

PORTS M.A. (1996). Habitat affinities and distributions of land gastropods from the Ruby Mountains and East Humboldt Range of northeastern Nevada. The Veliger 39: 335-341. Available from http:// biodiversitylibrary.org/page/42501470 [accessed 18 May 2017].

PRAWDZIC K. \& KoŹMIŃSKI C. (1972). Agroklimat województwa zielonogórskiego. Redakcja Poradnika Gospodarczego, Zielona Góra.

SANTOS X., Bros V. \& Ros E. (2012). Contrasting responses of two xerophilous land snails to fire and natural reforestation. Contributions to Zoology 81: 167-180.

SHARLAND E.C. (2001). Autecology of Vertigo angustior and Vertigo geyeri in Wales. Ph.D. Thesis. University of Sheffield, UK.

StAŃKo R. \& WoŁeJKo L. (2001). Plan ochrony rezerwatu przyrody „Dolina Ilanki” na lata 20022021. Lubuski Klub Przyrodników, Pracownia Ochrony Przyrody, Świebodzin.

StOLl P., GATZSCH K., RUSTERHOLZ H.P. \& BAUR B. (2012). Response of plant and gastropod species to knotweed invasion. Basic and Applied Ecology 13: 232-240. https://doi.org/10.1016/j.baae.2012.03.004 
SULIKOWSKA-DrozD A. \& HorsÀK M. (2007). Woodland mollusc communities along environmental gradients in the East Carpathians. Biologia (Bratislava) 62: 201-209. https://doi.org/10.2478/s11756$\underline{007-0030-7}$

Szlauer-Łukaszewska A., Wilhelm M. \& Sulikowska-Drozd A. (2015). The occurrence of protected vertiginids Vertigo angustior Jeffreys, 1830 and Vertigo moulinsiana (Dupuy, 1849) in the estuary of the Odra river. Folia Malacologica 23: 225-234. https://doi.org/10.12657/folmal.023.019

SZybiak K., BŁoszyK J., KoralewsKa-BATURA E. \& GoŁdyN B. (2009). Small-scale distribution of wintering terrestrial snails in forest site: relation to habitat conditions. Polish Journal of Ecology 57: $525-535$.

TATTERSFIELD P. \& MCINNES R. (2003). Hydrological requirements of Vertigo moulinsiana on three candidate Special Areas of Conservation in England (Gastropoda, Pulmonata: Vertiginidae). Heldia 5: $135-147$.

WALDÉN H.W. (1981). Communities and diversity of land molluscs in Scandinavian woodlands. I. High diversity communities in taluses and boulder slopes in SW Sweden. Journal of Conchology 30: 351-372.

WÄREBORN I. (1969). Land molluscs and their environments in an oligotrophic area in southern Sweden. Oikos 20: 461-479.

Willig M.R., SANDLIN E.A. \& GANNON M.R. (1998). Structural and taxonomic correlates of habitat selection by a Puerto Rican land snail. The Southwestern Naturalist 43: 70-79.

WoŁejko L. \& Stańko R. (1998). Doliny Ilanki i Pliszki jako ostoje bioróżnorodności. Zielona wstega Odra-Nysa. Wydawnictwo Lubuskiego Klubu Przyrodników, Świebodzin.

WoŁejKo L., StAŃKo R. \& PAWlikowski P. (2008). Poradnik utrzymania i ochrony siedliska przyrodniczego 7230-torfowiska alkaliczne. Klub Przyrodników, Świebodzin-Warszawa.

Wolejko L., Stańko R., Pawlikowski P., Jarzombkowski F., Kiaszewicz K., Chapiński P., BREGIN M., KOZUB Ł., KRAJEWSKI Ł. \& SZCZEPAŃSKI M. (2012). Krajowy program ochrony torfowisk alkalicznych (7230). Wydawnictwo Klubu Przyrodników, Świebodzin.

WiKTOR A. 2004. Ślimaki lądowe Polski. Wydawnictwo Mantis, Olsztyn.

ZARZYCKI K., TRZCiŃSKA-TACiK H., RÓŻAŃSKi W., SZElĄG Z., WoŁeK J. \& KorZENIAK U. (2002). Ecological indicator values of vascular plants of Poland. [Ekologiczne liczby wskaznikowe roślin naczyniowych Polski.] Instytut Botaniki im. W. Szafera, Polska Akademia Nauk, Kraków.

Manuscript received: 13 June 2016

Manuscript accepted: 5 December 2016

Published on: 18 July 2017

Branch editor: Kurt Jordaens 